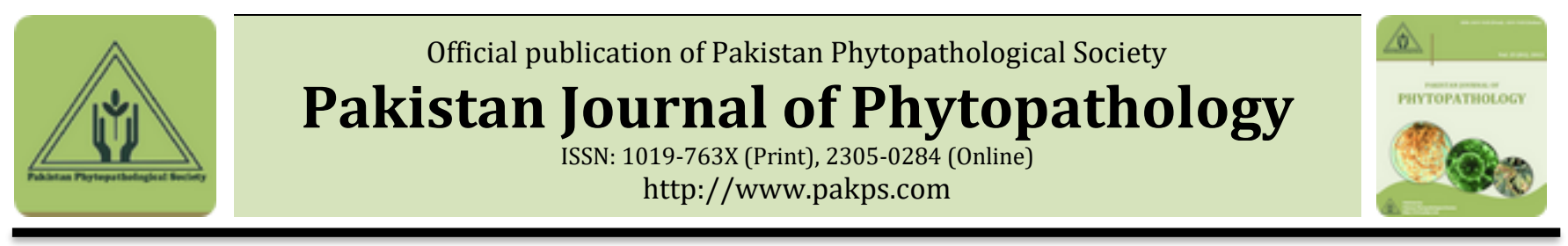

\title{
POTENTIAL OF PLANT EXTRACTS AND FUNGICIDES FOR MANAGING FUSARIUM OXYSPORUM F. SPLYCOPERSICI
}

\author{
a,bGulBahar Poussio, aManzoor A. Abaro*, aJamal A. Hajano, aMuhammad I. Khaskheli, cShafique A. Memon \\ a Plant Pathology Section, Agriculture Research Institute (ARI), Tando Jam, Pakistan. \\ ${ }^{b}$ Department of Plant Protection, Sindh Agriculture University, Tando Jam, Pakistan. \\ c Department of soil Science, Sindh Agriculture University, Tando Jam, Pakistan.
}

\section{A B S T R A C T}

Fusarium oxysporum f.sp. lycopersici (FOL) is a highly destructive fungal pathogen of tomato crop causing wilt disease which may reduce 10 to $90 \%$ yield. In Pakistan, tomato is widely grown in Sindh province, major territories are district Hyderabad, Tando Allahyar and Mirpurkhas. Thus, surveys of these territories were conducted to record intensity of the disease and confirm etiology. Furthermore, potential of different botanical pesticides and commercially available fungicides were tested to inhibit mycelial growth of the causal fungus. The experiment was laid down with complete randomized block design with three replications. The results showed that the disease was occurring in all locations with the range of 8-47 \% incidence. F. oxysporum f.sp. lycopersici was predominantly isolated from the collected disease sample during survey and pathogenic nature of the fungus was tested on the tomato Golo variety through soil drenching method. The disease incidence of 30 and $42 \%$ (72\% as total) was recorded in inoculated tomato plants at 20 and 40 DAI, respectively. Maximum (67\%) inhibition of the fungal growth was found by neem seed extracts at higher dose of $8 \%$ concentration followed by $63 \%$ with neem seeds and Eucalyptus at 6 and $8 \%$, respectively. Alternatively, the Nativo 75 WG fungicide was found most effective in reducing the redial mycelial growth of target fungus followed by Topsin-M at $1000 \mathrm{ppm}$ where as Aliette and Melodedue fungicides were found least effective under in-vitro conditions.

Keywords: Tomato, Fusarium oxysporum, Incidence, Botanical pesticides, Fungicides.

\section{INTRODUCTION}

Tomato is considered highly nutritive and widely grown vegetables in 144 countries of the world. Among them China, United States, Turkey, India and Egypt are the top most tomato producing countries of the world in metric ton production. The total area under cultivation of tomato is $45,82,438$ thousand ha. Whereas, the production 15051381 thousand tones and productivity of 32.8 tones/ha has been recorded in the world (FAO, 2016).

It is the second major vegetable, produced in Pakistan after potatoes (Mirza, 2007). In Pakistan tomato crop is

Submitted: May 13, 2018

Revised: May 28, 2018

Accepted for Publication: June 13, 2018

* Corresponding Author:

Email: mmanzoorabro@hotmail.com

(C) 2017 Pak. J. Phytopathol. All rights reserved. grown on area of 62.6 thousand hectares which produces 587.1 thousand tons with an average yield of 9.4 thousand tons per hectare (GOP, 2016). Sindh province is major tomato producing region of Pakistan, where the crop is grown on an area of 27.9 thousand hectares with total production of 206.5 thousand tones and 7.4 thousand tones yield per hectare (GOP, 2016). This average yield is lowest as compare to other provinces of Pakistan (GOP, 2016). It is very important vegetable, having much nutritional value at comparatively low prices as compare to other vegetables. It has $95.3 \%$ water, $0.07 \%$ calcium and niacin, Vitamin A, C, E and rich source of nutrients like $\mathrm{Na}, \mathrm{K}, \mathrm{Fe}$, and antioxidants especially lycopene and salicylate. All of have great importance in human metabolic system. Tomato fruit is commonly consumed in our daily life in different modes, such as vegetables, 
salad, ketchup, chatni and other dishes (Afzal et al., 2013; Chohan and Ahmad, 2008).

The yield per hectare is lower as compared to other countries due to attack of several pathogens that are responsible for damaging the quantity and quality of the crop every year. Among them, Fusarium oxysporum f.sp. lycopersici is one of destructive soil borne fungal pathogen, causing wilt disease in tomato (Rai et al., 2011). In culture it produces white aerial mycelium often with pink, orange, red, blue, violet or purple pigmentation developing with age. It can also produce slimy clump of spores (sporodochia) and blue sclerotia in culture (Windles, 1992). Fusarium oxysporum f.sp. lycopersici can produces three types of asexual spores, macro and micro conidia and chlamydospores depending on culture conditions. Macro conidia are usually produced abundantly as long, sickle-shaped, thin-walled, spores with several septa. Micro conidia are also usually abundant and are smaller single- celled, oval-shaped spores. The production of micro conidia on short monophialides is a distinguishing characteristic. Chlamydo spores are thick-walled, round; dormant spores are formed singly or in pairs. It is typically produced in 2-4 weeks on old culture (Nelson, 1983)

It was first reported in England in 1895 by G.E Massee. The fungus is prevailing in 32 countries where the environmental conditions are warm (Mui- Yun Wong, 2003). The symptoms produced by Fusarium wilt disease of tomato include drooping, yellowing, wilting, and dying of the lower leaves, often on one side of the plant. These symptoms may appear on successively younger leaves with one or more branches being affected and others remaining healthy. After a few weeks, browning of the vascular system may be observed by slicing the stem open lengthwise with a knife. This brown discoloration inside the stem can be found from the roots to the top of the plant. Plant growth is stunted, and, under warm conditions, the plant may die (Kenneth et al., 2014). 10 to $90 \%$ losses in yield occurs due to the attack of Fusarium wilt disease of tomato (Singh and Kamal, 2012). Management of this fungus is difficult due to their endophytic growth and longer persistence in soil according to Borrero et al. (2006) and Haridon et al. (2011). In Pakistan the fungus is managed using integrated practices such as, cultivation of resistant varieties, systemic induced or acquired resistance and application of bio-control agents (Hussain et al., 2013; Sultana et al., 2013; Shafique et al., 2015; Hussain et al., 2013; Fatima and Anjum, 2017). Even though, such practices are efficiently and safely managing the fungal development but are either time consuming or unavailable for commercial purpose. Additionally, genetic variation among the fungus population may overcome the effectiveness of such practices and lead to develop epidemics in this region. Alternatively, application of plant extracts and fungicides are choice of practices for farmers to manage the yield losses. Previously, worker determined potential of such plant extracts and fungicides (Sultana and Ghaffar, 2013; Fareed et al., 2015). However, the samples of tomato plant showing fusarium wilt disease were collected from different region of Sindh Pakistan that may change its behavior against tested plant extracts and fungicides. Therefore, in this study, we determined effectiveness of various plant extracts and fungicides under in-vitro conditions.

\section{MATERIALS AND METHODS}

Disease incidence \%: Fusarium wilt disease incidence was recorded from different locations of tomato growing districts of Sindh viz., Hyderabad (Neon Shehar, Bodani, Bhitae Masjid and Jeay Shah), Tando Allahyar(Darya khan Nahiyon, Dhigano Bazdar, Ilyas Khanzada ,Javed Khanzad,), and Mirpurk has(Bashirabad, Kachhelo farm, Mian saleem, Dehal gar)during 2015-2016.

The disease incidence \% was recorded from each location by using the following formulae:

$$
\text { Disease incidence } \%=\frac{\text { Number of diseased plant observed }}{\text { Total number of plants observed }} \times 100
$$

Isolation and identification of $\boldsymbol{F}$. oxysporum f.sp. lycopersici: Isolation was done from 200 small root pieces showing tomato wilt disease symptoms. The roots were cut from adjoining areas of the specimen from diseased and healthy areas of the plants. Root pieces were washed under tap water for about 30 minutes to remove any dirt or soil particle. The root pieces were dipped in $0.01 \% \mathrm{HgCl} 2$ for about 2 minutes and then passed from two washes of distilled sterile water for 2-3 minutes each. The treated root pieces were dried completely and then transferred to Petri dishes containing sterilized potato-dextrose agar medium with 
five pieces per plate. All the plates were kept at $25 \pm 1^{\circ} \mathrm{C}$ for 7 days. The fresh growth of the fungi was transferred to freshly prepared potato-dextrose agar medium for sub culturing. The growth was sub-cultured/multiplied whenever needed during the entire study. The fungi isolated were identified by studying their typical mycelial growth produced on the potato dextrose agar medium and conidial morphology using standard diagnostic keys as described by Barnett and Hunter, (1972) and Ellis, (1971.

Pathogenicity test: The Pathogenicity test of Fusarium oxysporum f.sp. lycopersici was done on three weeks-old seedlings of tomato variety golo at rate of 3 seedlings per pot into earthen pots $(30 \mathrm{~cm}$. in diameter) each containing $2 \mathrm{Kg}$ of natural soil mixture consisted of clay and sand at rate of 2:1 (by weight). The spore suspension was adjusted $1 \times 10^{6}$ spores/ml (Omar et al., 2006). Then spore suspension of a particular Fusarium isolate was poured over stem base at rate of $20 \mathrm{ml} /$ seedling. In control, distilled water was used instead of spore suspension. Pots were irrigated and maintained in a green house at 28 to $32^{\circ} \mathrm{C}$ and $80 \%$ relative humidity. After forty days of inoculation the plants were uprooted and the data regarding number of diseased plants and disease incidence was taken after 20 and 40 days of inoculation. The disease incidence was calculated by following formulae:

$$
\text { Disease incidence }(\%)=\frac{\text { Number of infected seedling after inoculation }}{\text { Total number of seedlings used for inoculation }} \times 100
$$

Purification of $\boldsymbol{F}$. oxysporumf.sp. lycopersici: The isolated fungus, Fusarium oxysporum f.sp. lycopersici was maintained on potato dextrose agar (PDA) slants having optimum growth at $\mathrm{pH} 7.0$ and temperature $25+10 \mathrm{C}$. Sub culturing was done at monthly intervals to maintain the stock cultures and preserved at $15{ }^{\circ} \mathrm{C}$. Moreover, sub culture was maintained in sterilized Petri plates containing PDA for further studies.

Efficacy of plant extracts to inhibit mycelial growth of $\boldsymbol{F}$. oxysporum f. splycopersici: Bitter apple leaves (Citrullu scolocynthis), eucalyptus leaves (Eucalyptus obliqua) and neem leaves and seeds (Azardicaindica) and Ginger rhizome (Zingiber officinalis) were tested at four concentrations (2, 4, 6 and $8 \%$ ) against F. oxysporum f.sp. lycopersici using food poisoning method described by Singh and Tripathi (1994). The extract was prepared as 100 grams of fresh leaves were poured with $250 \mathrm{~mL}$ of water for 3-4 days and kept in shaking incubator for two days. The extracts were filtered by using Whatmann filter paper No.1 and then concentrated in vacuum at $40^{\circ}-50^{\circ} \mathrm{C}$ using a rotary evaporator. Evaporation of solvent in the rotary evaporator results crude extract from different solvents and these extracts were used against the target pathogen. There were three replications for each concentration and plates without amendment of extracts served as control. Inhibition \% was calculated using following formula given by Sundar et al. (1995). The obtained values were statistically analyzed using computer software STATISTIX v.8.1.

$$
\% \text { Inhibition }=100 \times \frac{\mathrm{X}-\mathrm{Y}}{\mathrm{Y}}
$$

$\mathrm{PI}=$ Percent inhibition in mycelial growth

$\mathrm{X}=$ Mycelial growth in control plate

$\mathrm{Y}=$ Mycelial growth in treated plate
Efficacy of different fungicides to inhibit mycelial growth of $\boldsymbol{F}$. oxysporum f.sp. lycopersici: The fungicides viz. Cabriotop, Melodedue, Nativo, Topsin-M and Aliette were tested by food poisoning techniques at 10, 20, 100, 200, 500 and $1000 \mathrm{ppm}$ concentrations under in-vitro conditions. The required concentrations of tested fungicides were made in separate conical flasks containing sterilized PDA. These PDA flasks were poured in @ 20ml per plate. PDA plates without fungicides were served as control. Each plate was inoculated with a $5 \mathrm{~mm}$ disc of seven days old culture oftarget fungus in the centre of Petri plate containing sterilized PDA and incubated at $25{ }^{\circ} \mathrm{C}$. Three replicates in a completely randomized design were used within each treatment. The radial mycelial colony growth of the test fungus was recorded in millimetre after every 24 hrs till the control plates become full with the mycelial growth of the fungus. The inhibition percent of the all tested fungicides against Fusarium oxysporum f.sp. lycopersici was determined using formula described by Sundar et al. (1995). The obtained values were statistically analyzed similar as above.

$\mathrm{PI}=$ Percent inhibition in mycelial growth

$$
\% \text { Inhibition }=100 \times \frac{\mathrm{X}-\mathrm{Y}}{\mathrm{Y}}
$$

$\mathrm{X}=$ Mycelial growth in control plate

$\mathrm{Y}=$ Mycelial growth in treated plate

RESULTS AND DISCUSSIONS

Disease incidence in different locations: The major tomato growing locations of district Hyderabad, Tando Allahyar and Mirpurkhas were surveyed to estimate the disease incidence of Fusarium wilt disease. The disease was found at all localities surveyed with range between8.3 to 47.0incidences (Figure 1). In district Hyderabad the maximum disease incidence \% was found at Bodani (47.0) followed by Neonshehar (43.0) and 
there was non-significant variation in incidence at Jeay Shah and Bhitae Masjid (38.667 and36.3), respectively. Whereas in district Tnado Allahyar, the maximum incidence of 25.3 was recorded at DhiganoBazdar and 12, 10 and $8.3 \%$ were recorded at Darya khan Nahiyon, Ilyas Khanzad and Javed Khanzad, respectively. In district Mirpurkhas22 \% incidence was recorded at Kachhelo farm and there was non-significant difference at other three localities. The results are showing that the disease is more prevalent in district Hyderabad as compare to Tando Allahyar and Mirpurkhas. Such variation among incidence values at different localities of the same region is reported by Jiskani et al. (2007) among damping off disease of tomato. This indicates there is adequate variation in the region for susceptibility of host plants to pathogens or infection potential of the pathogens. This might be due to favourable environmental conditions, management practice of the growers, involvement of different fungal races or preference of grown cultivars.

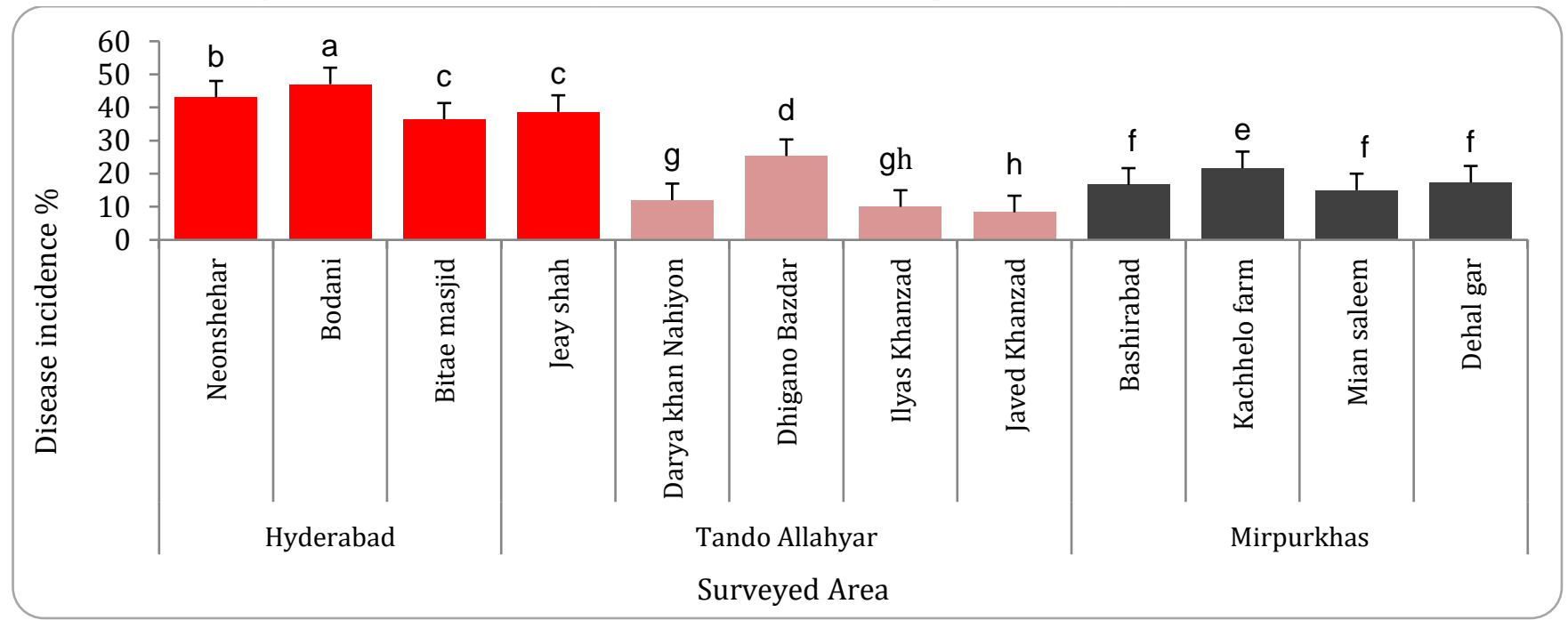

Figure 1. Disease incidence \% of major tomato growing areas of Sindh

Isolation and pathogenicity of $\boldsymbol{F}$. oxysporum f.sp. diseased at 20 day of inoculation, infection increased to lycopersici: The diseased symptoms were confirmed by isolating F. oxysporum f.sp. lycopersici from randomly collected specimens, which was identified taxonomic keys based on morphological characteristics as described by Barnett and Hunter, (1972) and Ellis, (1971).The pathogenicity test showed that 18 plants (30\%) were 25 plants ( $42 \%$ ), whereas in control no plant showed the disease symptoms (Figure 2). This result confirmed pathogenic nature of $F$. oxysporum $\mathrm{f}$. splycopersici, similar as Ignjatov et al. (2012) confirmed pathogenic potential of different Fusarium isolates with artificial inoculation in soil and plants showed wilting symptoms.

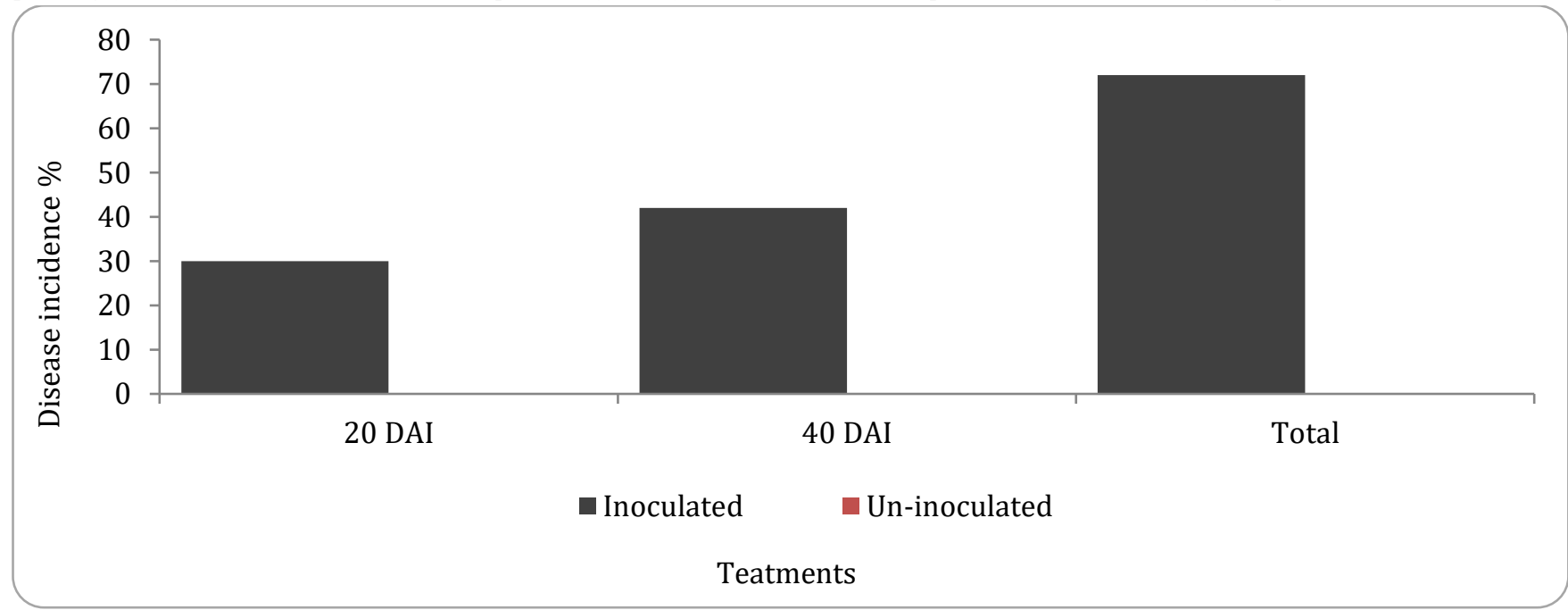

Figure 2. Pathogenicity test of F oxysporum f. splycopersici on local tomato variety Golo 
Efficacy of plant extracts against Fusarium oxysporum f.sp. lycopersici: Bitter apple leaves, eucalyptus leaves and neem leave as well as seeds and Ginger rhizome were tested at four concentrations like 2, 4,6 and $8 \%$ against the fungus under in-vitro conditions and showed various responses to inhibit mycelial growth. In general, higher concentration showed more inhibition of mycelial growth (Figure 3). The neem seed extracts were found the most effective at all applied doses as compare to other plant extracts. The maximum (66.2) \% inhibition was found by neem seed extracts followed by $63.3,58.5,55.9$ and $55.6 \%$ by Eucalyptus, neem leaves, ginger rhizome and bitter apple respectively, at $8 \%$ concentrations The minimum inhibition of $35.6 \%$ and $40.0 \%$ of the fungal growth was found in extracts of bitter apple and ginger rhizome at $2 \%$ concentrations (Figure 3). Chohan et al. (2011) assessed effects of five medicinal plants against $F$. oxysporum $\mathrm{f}$. sp.gladioli under in-vitro and they found $A$. indica extract was most effective to inhibit mycelial growth at higher concentration. In another study Shafique et al. (2015) determined potential of extracts prepared from Eucalyptus citriodora fruit, bark and leaves at various concentrations against $F$. oxysporum, which is significantly suppressed leaf extract as compare to other remaining parts.

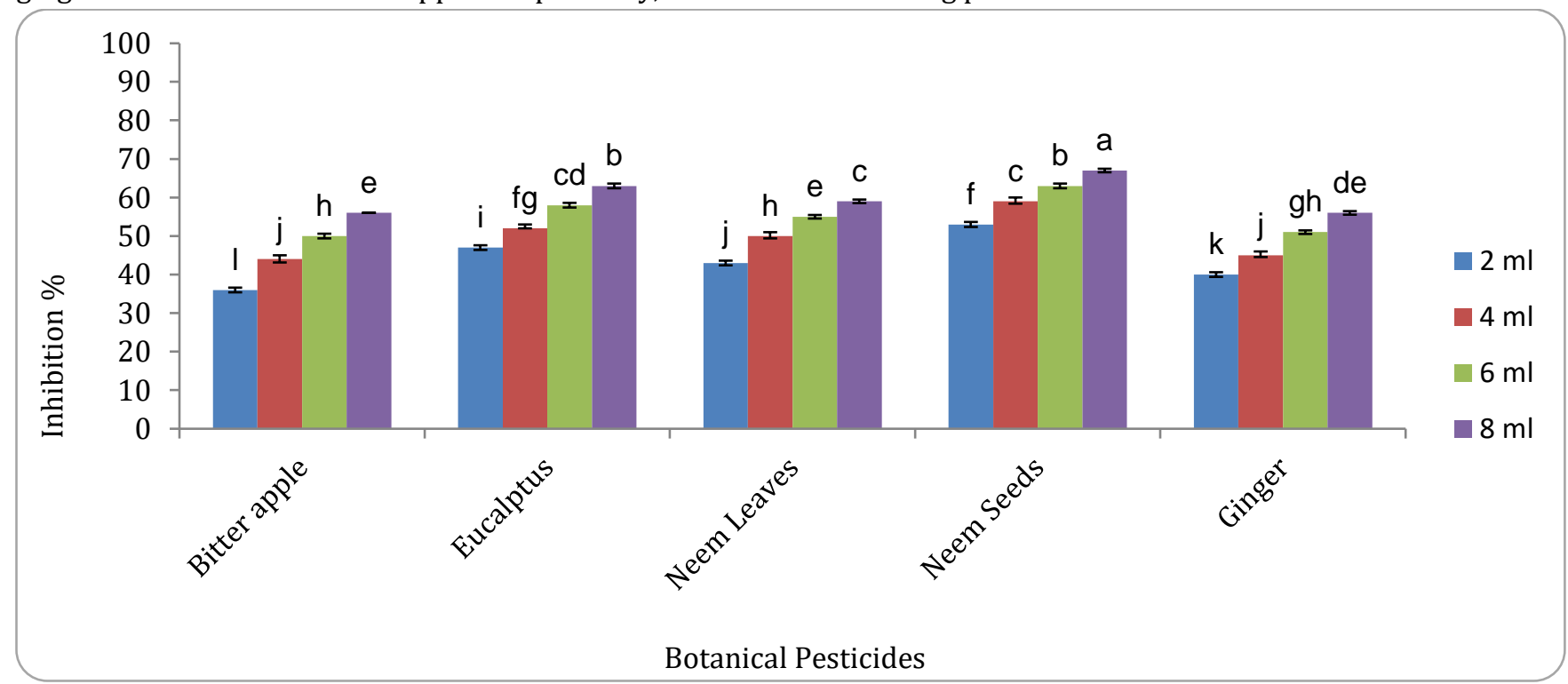

Figure 3. Effect of different plant extracts on the mycelia growth of $f$ oxysporum f.sp. lycopersici.

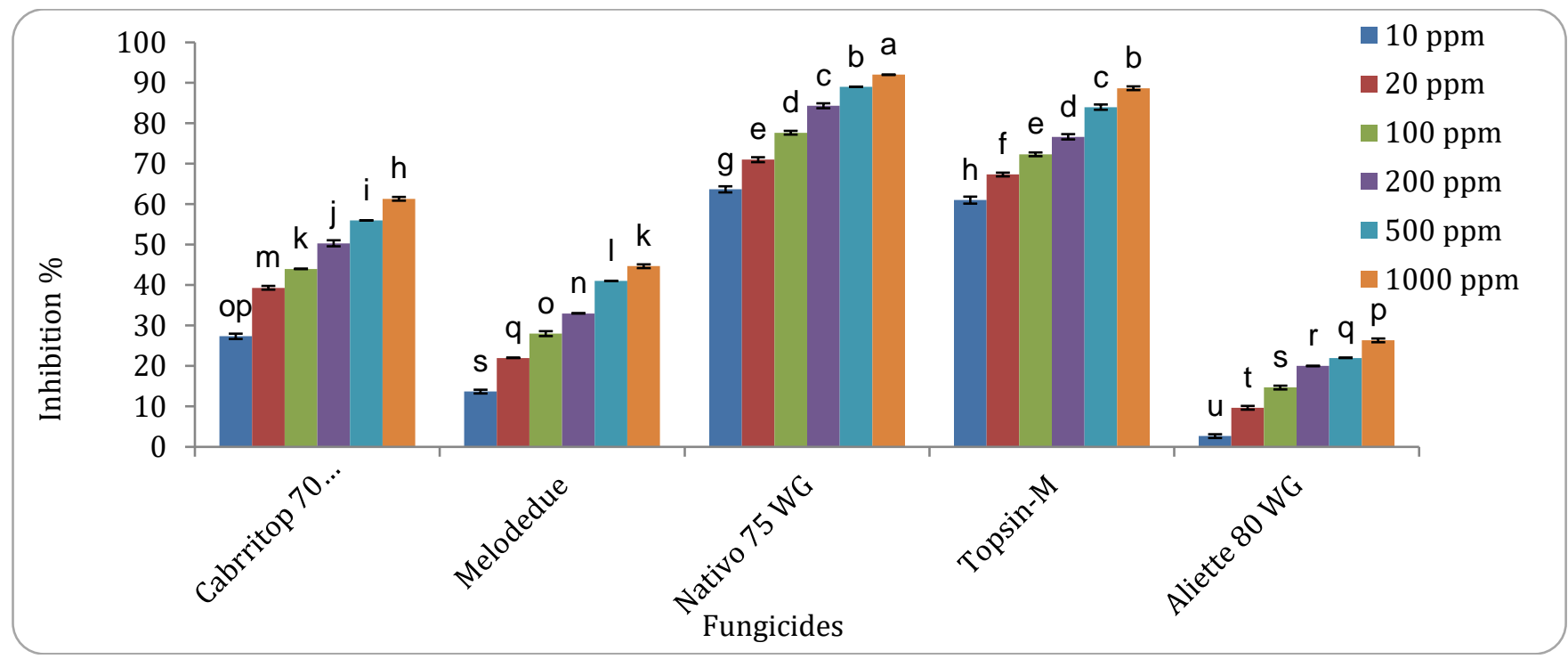

Figure 4. Effect of different fungicides on the mycelia growth of Fusarium oxysporum f.sp. lycopersici 
Efficacy of different fungicides against Fusarium oxysporum f. sp. lycopersici: Cabriotop, Melodedue, Nativo, Topsin-M and Allieate fungicide widely available for commercial purpose amended at different concentrations in PDA inhibited growth of the fungus. The Nativo was found the most effective fungicides (write digital values)for reducing the redial mycelial colony growth of target fungus followed by Topsin-M at 1000 ppm (write digital values) where as Aliette (provide value) and Melodedue (write digital values) fungicides were found least effective as compare to other fungicides. The Cabriotop was found as moderated effective fungicide (value) in reducing the mycelial growth of target fungus under in-vitro conditions (Figure 3). Sultana and Ghaffar, (2013) found that Aliette, Benlate and Carbendazim fungicides completely inhibit the colony growth of $F$. oxysoprum @ 100 ppm whereas Mancozeb, Ridomil, Topsin-M and Vitavax completely inhibited the colony growth at $1000 \mathrm{ppm}$. Fareed et al. (2015) showed Ridomil as effective to control growth of cucumber fusarium wilt causing fungus as to compare to Score, Copper oxychloride, Cabriotop, and Antracol.This is indicating that $F$. oxysoprum infecting different crops or in different regions may chance its response to fungicides.

\section{CONCLUSION}

It is concluded that the Fusarium wilt disease of tomato is prevalent in all major tomato growing areas of Sindh with different ranges. As for as its management the fungicides were found most effective as compare to plant extracts. The Native and Topsin-M Fungicides were the most effective fungicides followed by Neem seed and Eucalyptus plant extracts at their higher concentrations.

\section{REFERENCES}

Afzal, I., F. Munir, C. M. Ayub, S. M. A. Basra, A. Hameed and F. Shah. 2013. Ethanol priming: an effective approach to enhance germination and seedling development by improving antioxidant system in tomato seeds. Acta Scientiarum Polonorum Horticulture, 12: 129-137.

Barnett, H.L. and B.B. Hunter. 1972. Illustrated Genera of Imperfect Fungi, 4th ediyion. Burgess Publication Ltd. St.Paul, Minnesota, USA, 1-216.

Borrero, C., J. Ordovás, M. I. Trillas and M. Avilés. 2006. Tomato Fusarium wilt suppressiveness. The relationship between the organic plant growth media and their microbial communities as characterised by Biolog®. Soil Biology and
Biochemistry, 38: 1631-1637.

Chohan, S. R., M. Atiq, A. Mehmood, S. Naz, B. Siddique and G. Yasmin. 2011. Efficacy of few plant extracts against Fusarium oxysporum f. sp. gladioli, the cause of corm rot of gladiolus. Journal of Medicinal Plants Research, 5: 3887-3890.

Chohan, T. Z. and S. Ahmad. 2008. An assessment of tomato production Practices in Danna Katchely, Azad Jammu Kashmir. Pakistan Journal of Life and Social Sciences, 6(2): 96-102.

Ellis, M. B. 1971. Dematiaceous Hyphomycetes. Commonwealth Mycological Institute, Kew, Surrey, England.

FAO. 2016. Agricultural data FAOSTAT. Food and Agriculture Organization of the United Nations. Rome, Italy.

Fareed, G., M. Atiq, M. Abbas, M. Usman, and G. Abbas. 2015. In -vitro and in -vivo management of Fusarium wilt of cucumber through various chemicals. Advances in Zoology and Botany, 3: 169-174.

Fatima, S. and T. Anjum. 2017. Potential of rhizospheric pseudomonas strains to manage fusarium wilt of tomato. J. Agric. Res, 55: 525-536.

GOP. 2016. Pakistan Statistical Year Book. Government of Pakistan, Ministry of Statistics, Statistics Division.

Hussain, F., S. Shaukat, M. Abid, Farzana and M. Akbar. 2013. Control of some important soil-borne fungi by chitin associated with chilli (capsicum annuum 1.) In lower Sindh. Pakistan Sciences technology and development, 32: 228-234.

Ignjatov, M., D. Milosevic, Z. Nikolic, J. GvozdanovicVarga, D. Jovicic and G. Zdjelar. 2012. Fusarium oxysporum as causal agent of tomato wilt and fruit rot. Pesticidi i fitomedicina, 27: 25-31.

Jiskani, M. M., M.A. Pathan, K.H. Wagan, M. Imran and H. Abro. 2007. Studies on the control of tomato damping-off disease caused by Rhizoctonia solani Kuhn. Pakistan Journal of Botany, 39: 2749-2754.

Kenneth, W. S. 2014.-15. Tomato wilt problems (plant pathology fact sheet). PPFS-VG. Cooperative Extension Service University of Kentucky College of Agriculture, Food and Environment.

L'Haridon, F., S. Aimé, S. Duplessis, C. Alabouvette, C. Steinberg and C. Olivain. 2011. Isolation of differentially expressed genes during interactions between tomato cells and a protective or a non- 
protective strain of Fusarium oxysporum. Physiological and Molecular Plant Pathology, 76: 9-19. Mirza, I. 2007. Tomato paste plant to be set up at KillaSaifullah. Available at http://www.pakissan.com/ english/ news/ news Detail.php?newsid $=15041$.

Mui-YunWong. 2003. NC State University. PP728 Soil borne Plant Pathogen Class Project. https://www.cals.ncsu.edu/course/pp728/Fusari um/Fusarium_oxysporum.htm.

Nelson, P. E., T.A. Toussoun and W.F.O. Marases 1983. Fusarium Species: An Illustrate Manual for Identification. University Park, U.S.A Pennsylvania State University Press.

Omar, I., T. M. O'Neill and S. Rossall. 2006. Biological control of Fusarium crown and root rot of tomato with antagonistic bacteria and integrated control when combined with the fungicide carbendazim. Plant Pathology, 55: 92-99.

Rai, G. K., R. Kumar, J. Singh, P.K. Rai and S.K. Rai. 2011. Peroxidase, Polyphenol oxidase activity. Protein profile and phenolic content in tomato cultivars tolerant susceptible to Fusarium oxysporum f.sp. lycopersici. Pakistan Journal of botany, 43: 29872990.
Shafique, S., A. Muhammad and S. Shafiq. 2015. Management of fusarium Fusarium oxysporum $\mathrm{f}$. Sp. Capsici by leaf extract of eucalyptus citriodora. Pakistan Journal of Botany, 47: 1177-1182.

Singh, J., A. K. Dubeyd and N. N. Tripathi. 1994. Antifungal Activity of Mentha spicata. Pharmaceutical Biology, 32: 314-319.

Singh, K., A. Kamal and Shashi. 2012. Chemical Control of Wilt in Tomato Lycopersicon esculentum L. International Journal of Horticulture.

Sultana, N. and A. Ghaffar. 2013. Effect of fungicides, microbial antagonists and oil cakes in the control of Fusarium oxysporum, the cause of seed rot and root infection of bottle gourd and cucumber. Pakistan Journal Botany, 45: 2149-2156.

Sundar, A. R., N.D. Das and D. Krishnaveni 1995. In vitro Antagonism of Trichoderma spp. against two Fungal Pathogens of Castor. Indian Journal Plant Protection, 23: 152-155.

Windles, C. E. 1992. Fusarium. In: Methods for Research on Soil-Borne Phytopathogenic Fungi. Singleton, L.L. Mihail J.D. Ruch C.M. (eds). St. Paul, M.N., U.S.A. American Phytopathological Society Press, pp. PP115- 128. 